\title{
Risk Factors for Stunting Children Aged 6-59 Months In Pulau Panggung District, South Sumatera, Indonesia
}

\author{
Prihatina Anjela ${ }^{1 \#}$, Rachmat Hidayat ${ }^{2}$, Debby Handayati Harahap ${ }^{3}$ \\ ${ }^{1}$ General Practitioner, Pulau Panggung Public Health Center, Muara Enim \\ ${ }^{2}$ Biotechnology Laboratory, Faculty of Medicine, Universitas Sriwijaya \\ ${ }^{3}$ Medical Research Unit, Faculty of Medicine, Universitas Sriwijaya
}

\#Corresponding Author: n731_schoen@yahoo.com

Received : February $16^{\text {th }} 2018$

Accepted : March 25 2018

\begin{abstract}
Background :. Stunting among children is one of the major health problems in developing countries. Globally, $45 \%$ of deaths among children are caused by malnutrition, meanwhile stunting, as one of the factors, plays an important role. Children who experience stunting can not achieve optimal growth and cognitive potential. Hence, that will have an impact on future productivity. Muara Enim district is included in one district with stunting prevalence, which is above $20 \%$, i.e. $26.9 \%$. This study was to identify the risk factors of stunting children in Pulau Panggung district, Muara Enim, South Sumatera.

Methods: This study applied observational analytic research using cross sectional design. It was conducted on August to October 2017 at public health center in Pulau Panggung district, Muara Enim. There were 83 children who fullfilled the inclusion criteria. The relationship between risk factors and stunting was analyzed using $C h i$ square test and Logistic Regression test was applied to identify the risk factor that play the most role to stunting.

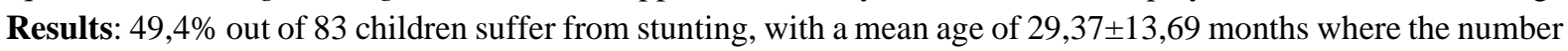
of children stunting with male gender is $53.7 \%$ while female gender is $46.3 \%$. Chi square analysis showed that there was a significant relationship among birth weight, birth length, mother's occupation, history of infection, exclussive breastfeeding and stunting $(\mathrm{p}<0.05)$ but no significant relationship was found among sex, mother's education, maternal height and income with stunting ( $>>0.05)$. Multivariate Logistic Regression test showed that mother's occupation and history of infection are the risk factors that contibute the most to stunting among children aged 6-59 months in Pulau Panggung district. The risk of stunting among working mothers is higher 5 times than unworking mothers and children with infection history have risk of stunting 3 times compared to children without infection history.
\end{abstract}

Conclusion: Mother's occupation and infection history are risk factors that contribute the most to stunting among children at Pulau Panggung district, Muara Enim, South Sumatera.

Keywords: Mother's Occupation, Infection History, Risk factors, Stunting.

\section{BACKGROUND}

Stunting is a nutritional status based on the Body Length index by Age (Length/Age) or Body Height by Age (Height/Age) which is the equivalent of the term stunted (short) and severely stunted (very short). ${ }^{1}$ Stunting is defined as percentage of children, aged 0 to 59 months with nutritional status based on length or height according to their age when compared to WHO- 
MGRS standard (Multicentre Growth Reference Study) 2005, z-scores less than -2SD and categorized very short if $\mathrm{z}$-scores less of $-3 \mathrm{SD} .^{1,2}$ Stunting reflects chronic undernutrition during the most critical periods of growth and development in early life. Stunting is associated with an underdeveloped brain, with long-lasting harmful consequences, including diminished mental ability and learning capacity, poor school performance in childhood, reduced earnings and increased risks of nutrition-related chronic diseases, such as diabetes, hypertension, and obesity in future. ${ }^{2}$

Globally, $45 \%$ of deaths among children are caused by malnutrition, where stunting as one of the factors plays an important role. ${ }^{3}$ The data got from UNICEF, WHO and the World Bank estimate that by 2016 there were 155 million (22.9\%) children under 5 in the world would experience stunting. One among four children worldwide experiences stunting (short) and as many as 87 million $(56 \%)$ of stunting children are found in Asia. ${ }^{4}$

Efforts to improve the community's nutritional status which include the decrease in stunting prevalence among children have become one of the national development priorities listed in the main target of the Medium Term Development Plan of 2015-2019., 5,

Based on the Monitoring of Nutritional Status Year 2016, stunting prevalence rate among children in South Sumatra Province reaches $19.2 \% .^{7}$ If stunting is related to the threshold of public health problems, this stunting event, which reaches $20 \%$ based on the prevalence of stunting in South Sumatra, is not considered low. In addition, Muara Enim District is included as one of the districts with stunting prevalence above $20 \%$, i.e. $26.9 \%$. This has become the major focus. ${ }^{8}$

\section{METHODS}

Observational analytic research with cross sectional design was applied on August to October 2017 at public health center in Pulau Panggung district, Muara Enim. There were 83 children who fullfilled the inclusion criteria. The inclusion criteria are children aged 6-59 months in Pulau Panggung district. They have complete data or information about the risk factors of stunting, and their parents agree to participate in this research. Information about the subjects was collected by interviewing their mother and taking data from growth monitoring cards.

Anthropometric measurements of mothers and children were taken using standardized body length with the precision of $0.1 \mathrm{~cm}$. Weight was measured using standardized digital flat scales, while height/length was measured using microtoise stature meter and length board for children. Anthropometric Z-scores for the children were generated using the WHO software WHO Anthro. Stunting was calculated on the basis of the WHO growth standards for children under 5 years of aged by measuring body length/height of the children and then was assessed by age. The frequency and distribution of children's data were described in univariate table form and the relationship between risk factors and stunting was analyzed using Chi square test. In addition, to identify the risk factor that plays the most role to stunting was conducted using Logistic Regression test.

\section{RESULT}

In total, there were 83 children aged 6-59 months participated in this reasearch, and 49,4\% out of 83 children suffered from stunting, with a mean age of $27.90 \pm 13.67$ months.

Table 1 illustrates the demographic characteristics of research subject. The majority of stunting 
was predominantly male gender $(53.7 \%)$ while female gender was $46.3 \%$. The majority of mother's education in stunting among children was senior high school, it was about $46.3 \%$ and predominantly, mother's occupation was as house wives (75.6\%).

Table 1. Characteristics Demographics of Research Subject

\begin{tabular}{|c|c|c|}
\hline \multirow{2}{*}{ Characteristics } & \multicolumn{2}{|c|}{ Stunting } \\
\hline & Yes & No \\
\hline $\begin{array}{l}\text { Age (months), } \\
\text { Mean } \pm \text { SD } \\
\text { Median (Min-Max) }\end{array}$ & $\begin{array}{c}27.90 \pm 13.67 \\
25(8-59) \\
\end{array}$ & $\begin{array}{c}25.14 \pm 15.03 \\
23(7-59)\end{array}$ \\
\hline $\operatorname{Sex}(n, \%)$ & & \\
\hline $\begin{array}{ll}\text { - } & \text { Male } \\
\text { - } & \text { Female } \\
\end{array}$ & $\begin{array}{l}22(53.7) \\
19(46.3)\end{array}$ & $\begin{array}{l}19(45.2) \\
23(54.8)\end{array}$ \\
\hline Mother Education, (n,\%) & & \\
\hline $\begin{array}{l}\text { - No School } \\
\text { - Elementary School } \\
\text { - Junior High School } \\
\text { - Senior High School } \\
\text { - Bachelor Degree } \\
\end{array}$ & $\begin{array}{c}3(7.3) \\
8(19.5) \\
8(19.5) \\
19(46.3) \\
3(7.3) \\
\end{array}$ & $\begin{array}{c}0(0) \\
4(9.5) \\
10(23.8) \\
26(61.9) \\
2(4.8)\end{array}$ \\
\hline $\begin{array}{c}\text { Mother Occupation }(\mathbf{n}, \%) \\
\text { - Work } \\
\text { - } \quad \text { No work } \\
\end{array}$ & $\begin{array}{l}10(24.4) \\
31(75.6) \\
\end{array}$ & $\begin{array}{c}2(4.8) \\
40(95.2)\end{array}$ \\
\hline
\end{tabular}

Table 2 below shows clinical characteristics of research subjects. It was found that the average birth weight of stunting children was as big as 3024.39 \pm 428.241 gram and average birth length was $47.61 \pm 1.883 \mathrm{~cm}$ with mother's height of stunting children was about $149.2 \pm 5.100 \mathrm{~cm}$. The prevalence of exclussive breastfeeding of 83 children aged 6-59 months was 39\% (16 children) and of non-exclussive breastfeeding was $61 \%$ ( 25 children). While the prevalence of infection history in stunting children was as many as 17 children $(41.5 \%)$.

Table 2. Clinical Characteristics of Research Subjects

\begin{tabular}{|c|c|c|}
\hline \multirow{2}{*}{ Characteristics } & \multicolumn{2}{|c|}{ Stunting } \\
\hline & Yes & No \\
\hline $\begin{array}{l}\text { Birth Weight (gram), } \\
\text { Mean } \pm \text { SD } \\
\text { Median (Min-Max) } \\
\end{array}$ & $\begin{array}{c}3024.39 \pm 428.241 \\
3000(2200-4000)\end{array}$ & $\begin{array}{l}3199.29 \pm 421.000 \\
3085(2300-4200)\end{array}$ \\
\hline $\begin{array}{l}\text { Birth Lenght }(\mathrm{cm}) \text {, } \\
\text { Mean } \pm \text { SD } \\
\text { Median (Min-Max) }\end{array}$ & $\begin{array}{c}47.61 \pm 1.883 \\
48(40-50)\end{array}$ & $\begin{array}{c}48.31 \pm 1.981 \\
48(44-52)\end{array}$ \\
\hline $\begin{array}{l}\text { Mother Height }(\mathrm{cm}) \\
\text { Mean } \pm \text { SD } \\
\text { Median (Min-Max) } \\
\end{array}$ & $\begin{array}{r}149.2 \pm 5.100 \\
150(141-161) \\
\end{array}$ & $\begin{array}{c}152.26 \pm 6.037 \\
152.5(138-166)\end{array}$ \\
\hline $\begin{array}{l}\text { Exclusive Breastfeeding, (n, \%) } \\
\text { - No } \\
\text { - Yes }\end{array}$ & $\begin{array}{l}25(61.0) \\
16(39.0)\end{array}$ & $\begin{array}{l}15(35.7) \\
27(64.3)\end{array}$ \\
\hline $\begin{array}{c}\text { Infection History }(\mathbf{n}, \boldsymbol{\%}) \\
\qquad \quad \text { Yes } \\
\bullet \quad \text { No } \\
\end{array}$ & $\begin{array}{l}17(41.5) \\
24(58.5)\end{array}$ & $\begin{array}{c}7(16.7) \\
35(83.3)\end{array}$ \\
\hline
\end{tabular}


Table 3. Relationship between Risk Factors and Stunting Among Children

\begin{tabular}{|c|c|c|c|c|}
\hline \multirow[t]{2}{*}{ Variabel } & \multicolumn{2}{|c|}{ Stunting } & \multirow[t]{2}{*}{ OR } & \multirow[t]{2}{*}{ P value } \\
\hline & Yes & No. & & \\
\hline \multicolumn{5}{|l|}{ Sex } \\
\hline - Male & $22(53.7)$ & $19(46.3)$ & 1.402 & 0.584 \\
\hline - Female & $19(45.2)$ & $23(54.8)$ & $(0.591-3.325)$ & \\
\hline \multicolumn{5}{|l|}{ Birth Weight } \\
\hline - Low Birth Weight $(<2500 \mathrm{~g})$ & $7(87.5)$ & $1(12.5)$ & 8.441 & 0.029 \\
\hline - $\quad$ Normal $(\geq 2500 \mathrm{~g})$ & $34(45.3)$ & $41(54.7)$ & $(0.989-72.036)$ & \\
\hline \multicolumn{5}{|l|}{ Birth Height } \\
\hline - $\quad<50 \mathrm{~cm}$ & $37(56.1)$ & $29(43.9)$ & 4.147 & 0.028 \\
\hline - $\quad \geq 50 \mathrm{~cm}$ & $4(23.5)$ & $13(76.5)$ & $(1.222-14.067)$ & \\
\hline \multicolumn{5}{|l|}{ Mother Education } \\
\hline - Low & $19(57.6)$ & $14(42.4)$ & 1.727 & 0.324 \\
\hline - High & $22(44)$ & $28(56)$ & $(0.711-4.197)$ & \\
\hline \multicolumn{5}{|l|}{ Mother Occupation } \\
\hline - Work & $10(83.3)$ & $2(16.7)$ & 6.452 & 0.013 \\
\hline - No work & $31(43.7)$ & $40(56.3)$ & $(1.317-31.605)$ & \\
\hline \multicolumn{5}{|l|}{ Infection History } \\
\hline - Yes & $17(70.8)$ & $7(29.2)$ & 3.542 & 0.025 \\
\hline - No & $24(40.7)$ & $35(59.3)$ & $(1,275-9.842)$ & \\
\hline \multicolumn{5}{|l|}{ Exclusive Breastfeeding } \\
\hline - No & $25(62.5)$ & $15(37.5)$ & 2.812 & 0.037 \\
\hline - Yes & $16(37.2)$ & $27(62.8)$ & $(1.155-6.849)$ & \\
\hline \multicolumn{5}{|l|}{ Maternal Height } \\
\hline - $\quad<150 \mathrm{~cm}$ & $20(58.8)$ & $14(41.2)$ & 1.905 & 0.227 \\
\hline - $\geq 150 \mathrm{~cm}$ & $21(42.9)$ & $28(57.1)$ & $(0.785-4.624)$ & \\
\hline \multicolumn{5}{|l|}{ Income } \\
\hline - $\quad<$ Regional Minimum Wage & $39(50)$ & $39(50)$ & 1.500 & 1.000 \\
\hline - $\quad \geq$ Regional Minimum Wage & $2(40)$ & $3(60)$ & $(0.237-9.477)$ & \\
\hline Total & 41 & 42 & & \\
\hline
\end{tabular}

Table 3 shows that the variables tested for association between risk factors and stunting among children aged 6-59 months. It revealed a significant relationship between birth weight and stunting $(\mathrm{OR}=8.441 ; \mathrm{p}=0.029)$, birth length and stunting $(\mathrm{OR}=4.147 ; \mathrm{p}=0.028)$, mother's occupation and stunting $(\mathrm{OR}=6.452 ; \mathrm{p}=0.013)$, infection history and stunting $(\mathrm{OR}=3.542$; $\mathrm{p}=0.025)$ and exclusive breastfeeding with stunting $(\mathrm{OR}=2.812 ; \mathrm{p}=0.037)$. In addition, there was no significant relationship between sex and stunting $(\mathrm{OR}=1.402 ; \mathrm{p}=0.584)$, mother's education and stunting $(\mathrm{OR}=1.727 ; \mathrm{p}=0.324)$, maternal height and stunting $(\mathrm{OR}=$ $1.905 ; \mathrm{p}=0.227)$ and income with stunting $(\mathrm{OR}=1.500 ; \mathrm{p}=1.000)$.

From the analysis of logistic regression, it was found out that mother's occupation and infection history were considered the risk factors that could contribute to stunting among children; meanwhile, working mother was considered having significant risk 5 times against stunting compared to mothers who do not work $(\mathrm{OR}=5.644 ; \mathrm{p}=0.049)$; and children with infection history had significant risk 3 times against stunting compared to children without infection history $(\mathrm{OR}=3.960 ; \mathrm{p}=0.020)$. 


\section{DISCUSSION}

In this study, it was found out that the risk factors, such as birth weight, birth length, mother's occupation, infection history, and exclussive breastfeeding had significant correlation with stunting. Research in Bangladesh has found a very strong positive association between low birth weight (LBW) and malnutrition among children under the age of five years in Bangladesh. For example, the risk of being underweight during the early years of childhood was found to be $47 \%$ higher among children with LBW than among children with normal birth weight even after being controlled by other factors in a multivariable model. ${ }^{9}$ A number of studies have reported that poor birth weight leads to an increasing risk of morbidity and mortality due to malnutrition. ${ }^{10,11,12}$

On the other hand, the link between LBW and child malnutrition could possibly be described by the increased vulnerability among children with LBW to infections, such as, diarrhea and lower respiratory infections and the increasing risk of complications including sleep apnea, jaundice, anemia, chronic lung disorders, fatigue and loss of appetite compared to children with normal birth weights. ${ }^{13,14-16}$ Greater morbidity among children with LBW results in poor physical growth and development that is perceived as malnutrition.

Based on the result, it can be concluded that the exclussive breastfeeding is considered one of the major factors contributing to children nutritional status. A study, conducted in Guinea, shows that the risk of morbidity is reduced close to 70 percents when a child is exclusively breastfed. Exclusive breastfeeding is protective against serious morbidities (diarrhea, respiratory infections and low growth) in the first six months of life. ${ }^{17}$ Experts recommend that children be breastfed within one hour after the birth, exclusively breastfed for the rest 6 months, and then breastfed until the age of 2 , which is considered age-appropriate, nutritionally adequate and safe complementary foods. Optimal feeding according to these standards can prevent an estimated 19 percents of all under-5 deaths. ${ }^{18}$

Previous study by Fikadu et.al, showed that children whose mothers worked as merchant and farmer were more likely to develop stunting than children whose mothers worked as house wives. This might be due to decreased contact time with the child that brings short period of exclusive breast feeding, early cessation of breast feeding, increasing exposure to bottle feeding and improper complementary food, which may have a large negative effect on the growth of the children. ${ }^{19}$ This results are not consistent with studies that had shown a protective effect of maternal employment by increasing income. Maternal employment may also positively influence food security, quality of diet and use of health services. ${ }^{20}$

This study also concludes that infection history has significant relationship with stunting. Both serious acute infections, particularly those that involve the gastrointestinal tract, and chronic infections impair linear growth. ${ }^{21,22}$ Symptomatic infection is common during the first years of life in low-income countries and repeated episodes of diarrhea or parasitic infection are associated with an increasing risk of stunting. ${ }^{23,24}$ One study suggested that $25 \%$ of stunting was attributed to five or more episodes of diarrhoea. ${ }^{25}$

The stunting syndrome identifies interactions between malnutrition and infection throughout the maternal, infant and child life cycle inhibiting growth. ${ }^{26}$ These interactions are mutually reinforcing through infection exacerbating any malnutrition, because of appetite suppression 
and reduced food intake, and any malabsorption reducing nutrient intake, while malnutrition reduces immune defence systems, thereby worsening the adverse influence of infections. ${ }^{27}$ Based on multivariate test, mother's occupation and infection history which significantly play an important role as the risk factor of stunting incident among children where working mothers have 5 times risk to have stunting children compared to mothers who do not work, and children with infection history have 3 times risk of experiencing stunting compared to children without infection history . This means that even if the child is born with a normal birth weight, normal birth lenght, exclusively breastfed, mother have normal height, high education, and family income above minimum wage, they will still have high risk of suffering from stunting if the mother works and they have an infection.

\section{CONCLUSION}

Mother's occupation and infection history are the risk factors that can contribute to stunting among children at Pulau Panggung district, Muara Enim, South Sumatera. The risk of stunting among working mothers is higher 5 times than unworking mothers and children with infection history have risk of stunting 3 times compared to children without infection history.

\section{REFERENCES}

1. Kementerian Kesehatan RI Direktorat Jenderal Bina Gizi dan Kesehatan Ibu dan Anak Direktorat Bina Gizi. 2011. Keputusan Menteri Kesehatan Republik Indonesia Nomor: 1995/MENKES/SK/XII/2010 Tentang Standar Antropometri Penilaian Status Gizi Anak.

2. UNICEF India. Stunting. (http://unicef.in/Whatwedo/10/StuntingDiakses 9 2017).

3. Black RE, Victora CG, Walker SP, Bhutta ZA, Christian P, de Onis M, et al. 2013. Maternal and Child Undernutrition and Overweight in Low-Income and Middle-Income Countries. The Lancet. 382:427-51. [PubMed].

4. UNICEF, WHO, World Bank Group. 2017. Levels and Trends in Child Malnutrition. Joint Child Malnutrition Estimates. New York, NY: United Nations International Children's Fund; Geneva: WHO; Washington, DC: World Bank. (https://data.unicef.org/resources/joint-child-malnutrition-estimates-2017-edition, Diakses 9 2017).

5. Peraturan Presiden Republik Indonesia Nomor 59 Tahun 2017 tentang Pelaksanaan Pencapaian Tujuan Pembangunan Berkelanjutan. 2017. Jakarta, hal.11-12.

6. Kementerian Kesehatan RI Pusat Data dan Informasi. 2016. Situasi Balita Pendek.

7. Kementerian Kesehatan RI Direktorat Jenderal Kesehatan Masyarakat Direktorat Gizi Masyarakat. 2017. Hasil Pemantauan Status Gizi (PSG) dan Penjelasannya Tahun 2016.

8. Dinas Kesehatan Sumatera Selatan. 2017.Jambore Ahli Gizi Dalam Rangka Penggalangan Komitmen Penurunan Stunting, Anemia Remaja Putri, Dan Anemia Ibu Hamil Di Provinsi Sumatera Selatan. http://dinkes.sumselprov.go.id.

9. Rahman MS, Howlader T, Masud MS, Rahman ML (2016) Association of Low-Birth Weight with Malnutrition in Children under Five Years in Bangladesh: Do Mother's Education, Socio-Economic Status, and Birth Interval Matter? PLoS ONE 11(6): e0157814. doi: 10.1371/journal.pone.0157814.

10. Haque SMR, Tisha S, Huq N (2015) Poor Birth Size a Badge of Low Birth Weight Accompanying Less Antenatal Care in Bangladesh with Substantial Divisional Variation: Evidence from BDHS - 2011. Pub- lic Health Research 5: 184-191. 
11. Dhar B, Mowlah G, Nahar S, Islam N (2002) Birth weight status of newborns and its relationship with other anthropometric parameters in a public maternity hospital in Dhaka, Bangladesh. J Health Popul Nutr 20: 36-41. PMID: 12022157.

12. Motta MEFA, da Silva GAP, Araújo OC, Lira PI, Lima M C (2005) Does birth weight affect nutritional sta- tus at the end of first year of life? J Pediatr 81: 377-382.

13. Khanal V, Sauer K, Karkee R, Zhao Y (2014) Factors associated with small size at birth in Nepal: further analysis of Nepal Demographic and Health Survey 2011. BMC Pregnancy and Childbirth 14:32. doi: 10.1186/1471-2393-14-32 PMID: 24438693.

14. Romero C, Duke J, Dabelea D, Romero T, Ogden L (2012) Does the epidemiologic paradox hold in the presence of risk factors for low birth weight infants among Mexican-born women in Colorado? J Health Care Poor Underserved 23 604-614. doi: 10.1353/hpu.2012.0065 PMID: 22643610.

15. Balci MM, Acikel S, Akdemir R (2010) Low birth weight and increased cardiovascular risk: fetal pro- gramming. Int J Cardiol 144: 110-111. doi: 10.1016/j.ijcard.2008.12.111 PMID: 19171387.

16. Anand D, Stevenson CJ, West CR, Pharoah POD (2003) Lung function and respiratory health in ado- lescents of very low birth weight. Arch Dis Child 88: 135-138. PMID: 12538315.

17. Haque M F, Hussain M, Sarkar A K, Hoque M M, Fakir Anjuman Ara and Sultana S: Breasrfeeding Counselling and its effect on the prevalance of Exclusive Breastfeeding; Journal of Health Population and Nutrition http://www.jhpn.net/index.php/jhpn/article/view/169.

18. Jones, Gareth, Richard Steketee, Robert E. Black, Zul qar Bhutta, and Saul Morris. "How Many Child Deaths Can We Prevent is Year?” e Lancet. Vol. 362, Issue 9377. July 5, 2003. pp.65-71.

19. Fikadu et al.: Factors associated with stunting among children of age 24 to 59 months in Meskan district, Gurage Zone, South Ethiopia: a case-control study. BMC Public Health 2014 14:800. http://www.biomedcentral.com/1471 2458/14/800.

20. Willey AB, Cameron N, Norris AS, Pettifor JM, Griffiths PL: Socio- economic predictors of stunting in preschool children: a population- based study from Johannesburg and Soweto. S Afr Med J 2009, 99:450-456.

21. SC Wong, R Dobie, MA Altowati, et al. (2016) Growth and the growth hormone-insulin like growth factor 1 axis in children with chronic inflammation: current evidence, gaps in knowledge and future directions. Endocr Rev 37, 62-110.

22. CB Stephensen (1999) Burden of infection on growth failure. J Nutr 129, 534S-538S.

23. BF Arnold, C Null, SP Luby, et al. (2013) Cluster-randomised controlled trials of individual and combined water, sanitation, hygiene and nutritional interventions in rural Bangladesh and Kenya: the WASH Benefits study design and rationale. BMJ Open 3, e003476.

24. RL Guerrant, RB Oriá, SR Moore, et al. (2008) Malnutrition as an enteric infectious disease with long-term effects on child development. Nutr Rev 66, 487-505.

25. W Checkley, G Buckley, RH Gilman, et al. (2008) Multi-country analysis of the effects of diarrhoea on childhood stunting. Int J Epidemiol 37, 816-830.

26. AJ Prendergast \& JH Humphrey (2014) The stunting syndrome in developing countries. Paediatr Int Child Health 34, 250-265.

27. Millward DJ. Nutrition, infection and stunting: the roles of deficiencies of individual nutrients and foods, and of inflammation, as determinants of reduced linear growth of children. Nutrition Research Reviews, Vol. 30, Issue 1. June 2017. pp. 50-72. 